\title{
Rheumatic symptoms following an outbreak of campylobacter enteritis: a five year follow up
}

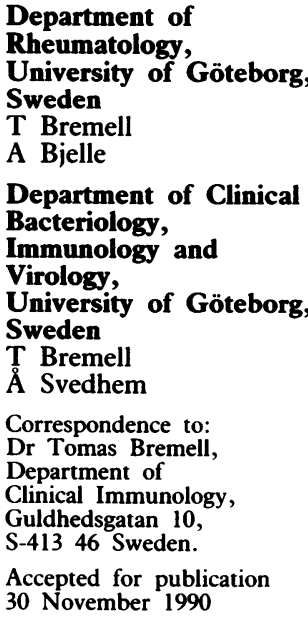

\begin{abstract}
Eighty six of $106(81 \%)$ guests attending a party were followed up after an outbreak of Campylobacter jejuni enterocolitis. Acute diarrhoeal illness was reported in 35 subjects (33\%), of whom seven showed acute rheumatic symptoms either alone or with other symptoms of infection with $C$ jejuni. The antibody response to $C$ jejuni corresponded well with the intensity of the disease. In the early phase of the gastrointestinal disease the patients with acute rheumatic symptoms displayed significantly higher IgM antibody levels in serum samples than the other patients in this study.

Levels of antibodies to $C$ jejuni were increased in serum samples from 31 patients (29\%) without symptoms of infection with $C$ jejuni. At a follow up after five and a half years, four of these patients suffered from chronic rheumatic disorders. One HLA-B27 positive woman developed reactive arthritis with a relapse seven years later. The remaining 20 subjects (19\%) remained healthy and their antibody tests and stool cultures were negative for $C$ jejuni.

It is concluded that $C$ jejuni enterocolitis is significantly associated with rheumatic symptoms in the early phase and may also cause chronic rheumatic disorders.
\end{abstract}

Arthritis following intestinal bacterial infections was first reported in 1916 by Reiter ${ }^{1}$ and Fiessinger and LeRoy. ${ }^{2}$ Certain bacteria have been more commonly found to cause reactive arthritis, e.g. certain strains of salmonella, shigella, and yersinia. More recently, associations between arthritic reactions and intestinal infections with Campylobacter fetus $^{3}$ and Campylobacter jejuni have been reported. ${ }^{4} 5$

There have been a few studies of the rheumatic implications after infections with $C$ jejuni ${ }^{6-9}$ In only one study, ${ }^{10}$ however, have the effects of a local demarcated outbreak of $C$ jejuni enteritis been analysed with respect to the development of arthritis.

We report here a five year follow up study of an outbreak of $C$ jejuni in 106 guests attending a party at which coq au vin, boiled rice, and fresh salad were served. This outbreak gave an opportunity to study the symptoms, signs, and natural course of musculoskeletal involvement following $C$ jejuni enterocolitis, including patients without overt gastrointestinal illness.

Materials and methods

SUBJECTS

A private party on 6 October 1981 was attended by 106 guests, all hospital staff members and their partners. Coq au vin (a chicken dish), boiled rice, and fresh salad were consumed by all the guests. After one to seven days 35 guests (33\%) experienced fever, diarrhoea, malaise, and/or headache. Within five to ten days 86 $(81 \%)$ of the guests were identified, interviewed, and their stools examined by routine bacteriological procedures. The remaining 20 participants did not reply to a questionnaire and were not included in the study (figure).

Early serum samples (S1) were obtained from 81 subjects 9-21 days (mean (SEM) 10.3 (0.2) days) after the party. A second serum sample (S2) was obtained from 49 of the subjects $16-42$ days after the party. The mean interval between S1 and S2 was 20.9 (0.7) days (range 5-33 days). Three subjects were admitted to hospital owing to severe enterocolitis. Two years after the infection all the 86 subjects interviewed were asked to complete a questionnaire about present or past rheumatic complaints. Answers were obtained from all 86 subjects. Five years after the party the 15 subjects who had reported locomotor symptoms were interviewed by telephone. Medical records were collected when available. Five subjects reporting long term locomotor symptoms starting after the party were examined clinically. The subjects knew about their bacteriological, but not their serological, test performed immediately after the party. The researchers were blind to the results of the bacteriological and serological tests when assessing the questionnaires.

\section{STOOL CULTURES}

All stool specimens were routinely processed to identify salmonella, shigella, yersinia and Clostridium difficile. The Skirrow medium was used to

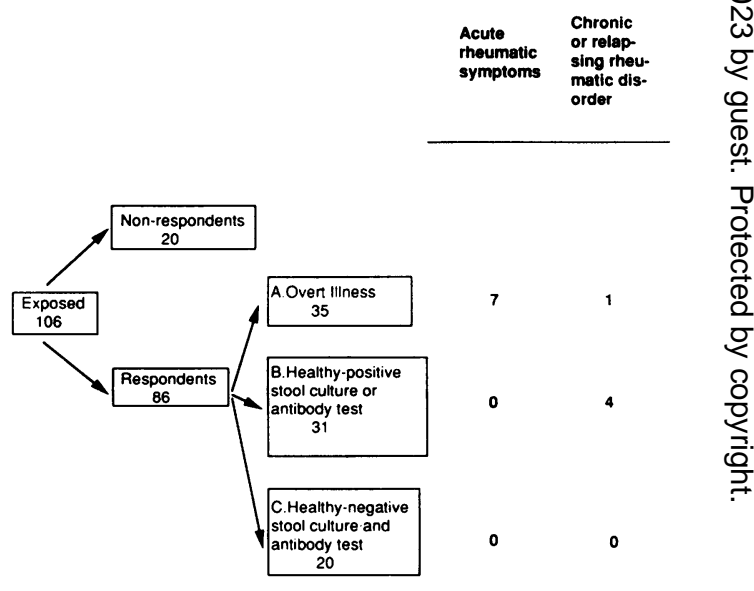

Evaluation of patients after exposure to $\mathrm{C}$ jejuni. 
culture campylobacter. ${ }^{11}$ All isolates were tested for hippurate.

\section{LEVELS OF ANTIBODIES TO $C$ JEJUNI IN SERUM SAMPLES}

The diffusion in gel enzyme linked immunosorbent assay (ELISA) was performed as described previously $^{12}$ to assess levels of antibodies to $C$ jejuni. A serum sample was considered as positive when the zone diameter exceeded $6 \mathrm{~mm}$ for the IgG and IgA class, or $5 \mathrm{~mm}$ for the IgM class.

\section{STATISTICAL ANALYSIS}

Comparisons were performed by Fisher's permutation test. ${ }^{13}$ Two sided tests were used. Confidence intervals were determined based on the assumption of a normal distribution. The $\chi^{2}$ and Fisher's exact test were used in some specified instances.

\section{DIAGNOSTIC CRITERIA}

Reactive arthritis is defined as an asymmetrical oligo synovitis with joint swelling, usually occurring within one month of the infection, and may also have associated enthesitis, symptomatic sacro-iliitis or dactylitis or the extra-articular features associated with Reiter's syndrome. When obvious joint swelling is not present the disease is designated as incomplete reactive arthritis.

\section{Results}

Eighty six of the 106 identified party guests

Table 1 Number of patients with rheumatic symptoms and/or signs following infection with $\mathrm{C}$ jejuni. Eighty six subjects were divided into three groups: $(A)$ with gastrointestinal symptoms of infection with $\mathrm{C}$ jejuni; $(B)$ without gastrointestinal symptoms but the laboratory findings indicative of infection with $\mathrm{C}$ jejuni; and $(C)$ without gastrointestinal symptoms or signs of infection with $\mathrm{C}$ jejuni

\begin{tabular}{llll}
\hline & $\begin{array}{l}\text { Group } A \\
(\mathrm{n}=35)\end{array}$ & $\begin{array}{l}\text { Group } B \\
(\mathrm{n}=31)\end{array}$ & $\begin{array}{l}\text { Group } C \\
(\mathrm{n}=20)\end{array}$ \\
\hline $\begin{array}{l}\text { Growth of } C \text { jejuni in stool } \\
\text { culture }\end{array}$ & 16 & 1 & 0 \\
$\begin{array}{l}\text { Increased levels of antibodies } \\
\text { to } C \text { jejuni in serum samples }\end{array}$ & 29 & 31 & 0 \\
$\begin{array}{c}\text { Acute rheumatic symptoms } \\
\text { and signs }\end{array}$ & & & \\
$\quad \begin{array}{l}\text { Incomplete reactive arthritis } \\
\text { Myalgia }\end{array}$ & 1 & 0 & 0 \\
$\quad \begin{array}{l}\text { Arthralgia } \\
\quad \text { Lumbalgia }\end{array}$ & 2 & 0 & 0 \\
$\begin{array}{l}\text { Chronic or relapsing rheumatic } \\
\text { disorder }\end{array}$ & 1 & 0 & 0 \\
$\quad$ & & \\
$\begin{array}{l}\text { Reactive arthritis } \\
\text { Arthralgia/enthesopathy }\end{array}$ & 1 & 0 & 0 \\
$\quad \begin{array}{l}\text { Sacroilitis } \\
\text { Enthesopathy }\end{array}$ & 0 & 1 & 0 \\
$\begin{array}{l}\text { Probable systemic lupus } \\
\text { erythematosus }\end{array}$ & 0 & 1 & 0 \\
\hline & 0 & 1 & 0 \\
\hline
\end{tabular}

Table 2 Sex, age, and type of profession in 86 guests at the party. Thirty five subjects (group $A$ ) had signs of infection with $\mathrm{C}$ jejuni, 31 subjects (group $B$ ) had no clinical symptoms but displayed seropositivity to $\mathrm{C}$ jejuni, and 20 subjects (group $C$ ) were clinically healthy without laboratory evidence of infection. No difference was found between the groups as tested by $\chi^{2}$ statistics

\begin{tabular}{lllll}
\hline Characteristic of patient & Group A & Group B & Group C & Total \\
\hline Male & 17 & 12 & 9 & 38 \\
Female & 18 & 19 & 11 & 48 \\
Mean age (SEM) (years) & $26 \cdot 9(0 \cdot 7)$ & $26 \cdot 9(1 \cdot 0)$ & $29 \cdot 9(1 \cdot 3)$ & $27 \cdot 6(0 \cdot 6)$ \\
Blue collar & 18 & 14 & 12 & 44 \\
White collar & 17 & 17 & 8 & 42 \\
\hline
\end{tabular}

were divided into three groups on the basis of clinical and laboratory characteristics (table 1). Patients with symptoms or signs of infection with $C$ jejuni (group A), subjects with no clinical symptoms or signs of infection but with an antibody test or a stool culture positive for $C$ jejuni (group B), and subjects with no symptoms or signs of infection with $C$ jejuni and with a negative antibody test and a negative stool culture (group C) were defined. No difference was found between the groups with respect to sex, age, or profession (table 2).

Thirty five subjects in group A reported various symptoms or signs of infection with $C$ jejuni. Most commonly reported were diarrhoea or gastrointestinal upset $(83 \%)$, fever $(71 \%)$, malaise $(71 \%)$, and headache $(69 \%)$. Sixteen patients in this group had positive stool cultures for Campylobacter jejuni and 29 of 34 tested serum samples showed significant levels of antibodies to $C$ jejuni. All of the campylobacter isolates were hippurate positive, indicating infection with $C$ jejuni.

Seven subjects $(20 \%)$ reported symptoms from joints, muscles, or spine (table 1), showing a significant ( $p<0.01$, Fisher's exact test) correlation between the occurrence of diarrhoea and rheumatic symptoms in the acute phase of the infection with $C$ jejuni. Six of these subjects had locomotor symptoms for less than one month. One patient (patient Al) had rheumatic symptoms for two months. She was admitted to hospital for five days owing to enterocolitis. Another two patients admitted to hospital owing to enterocolitis did not display rheumatic symptoms or signs.

The seven subjects with acute rheumatic complaints expressed significantly increased levels of $(p<0.05)$ serum IgM anti- $C$ jejuni antibodies in the early phase compared with the members of group A not displaying rheumatic symptoms (table 3 ).

Tests for antibodies to chlamydia, salmonella, yersinia, brucella and Francisella tularensis in the seven subjects with rheumatic symptoms were negative except for one with a salmonella DO complement fixation titre of $1 / 80$. This titre was regarded as a non-specific reaction as the patient had a positive stool culture for $C$ jejuni and negative culture for salmonella. Another individual had a low Chlamydia trachomatis antibody titre. Two subjects in group A reported a redness or soreness in their eyes. Another two subjects reported locomotor symptoms starting long before the party which were not changed by infection with $C$ jejuni. These two were not included among those with locomotor symptoms.

Thirty one subjects without overt acute illness in group B showed increased levels of antibodies to $C$ jejuni of at least one Ig class. In one subject the growth of $C$ jejuni was detected in stool culture. Four patients (patients B1-B4) reported long term rheumatic disorders starting three to eight months after the party. Patients B1-B4 were examined clinically 5.5 years after the exposure to $C$ jejuni and all their previous medical records were obtained. The IgG and IgA, but not $\operatorname{IgM}$, antibody titres to $C$ jejuni were constant and low in group $B$ compared 
with group A (table 3). Tests for antibodies to chlamydia, salmonella, brucella, Francisella tularensis and yersinia in the four patients with rheumatic symptoms were all negative. All patients in groups A and B tested for antibodies to rubella showed positive but constant antibody titres.

Twenty subjects in group $C$ showed neither signs of infection nor positive stool cultures. Sixteen subjects gave one serum sample and four also gave a second sample. All the serological tests and bacterial cultures were negative.

At the two year follow up no long term rheumatic disorders was reported by any of the 20 subjects in group $\mathrm{C}$.

\section{Case reports}

PATIENT A I

Patient A1 was a 25 year old HLA-B27 positive

Table 3 Levels of antibodies to $\mathrm{C}$ jejuni at 10.3 $\pm 0 \cdot 2$ and $31 \cdot 3 \pm 0 \cdot 6$ days after exposure. Antibody levels determined by diffusion in gel enzyme linked immunosorbent assay

\begin{tabular}{|c|c|c|c|}
\hline & \multirow[t]{2}{*}{ Antibody } & \multicolumn{2}{|c|}{ Days after exposure } \\
\hline & & 10 & 31 \\
\hline $\begin{array}{l}\text { Group A } \\
\text { No rheumatic complaints } \\
\text { Number of subjects } \\
\text { Mean (SEM) antibody level (mm) }\end{array}$ & $\begin{array}{l}\text { IgG } \\
\text { IgA } \\
\text { IgM }\end{array}$ & $\begin{array}{l}27 \\
6 \cdot 4(1 \cdot 1) \\
4 \cdot 4(0 \cdot 8) \\
5 \cdot 7(0 \cdot 5)\end{array}$ & $\begin{array}{l}19 \\
9 \cdot 1(1 \cdot 1) \\
5 \cdot 2(0 \cdot 6) \\
6 \cdot 8(0 \cdot 5)\end{array}$ \\
\hline $\begin{array}{l}\text { Acute rheumatic symptoms } \\
\text { Number of subjects } \\
\text { Mean (SEM) antibody level (mm)* }\end{array}$ & $\begin{array}{l}\text { IgG } \\
\text { IgA } \\
\text { IgM }\end{array}$ & $\begin{array}{l}7 \\
6 \cdot 9(2 \cdot 0) \\
5 \cdot 6(2 \cdot 1) \\
8 \cdot 2(0 \cdot 9) \dagger\end{array}$ & $\begin{array}{l}5 \\
11 \cdot 2(0 \cdot 5) \\
7 \cdot 1(0.8) \\
8 \cdot 8(1 \cdot 5)\end{array}$ \\
\hline $\begin{array}{l}\text { Group B } \\
\text { No rheumatic complaints } \\
\text { Number of subjects } \\
\text { Mean (SEM) antibody level (mm) }\end{array}$ & $\begin{array}{l}\text { IgG } \\
\text { IgA } \\
\text { IgM }\end{array}$ & $\begin{array}{l}27 \\
4 \cdot 2(0 \cdot 7) \\
2 \cdot 8(0 \cdot 5) \\
6 \cdot 2(0 \cdot 4)\end{array}$ & $\begin{array}{l}18 \\
4 \cdot 0(0 \cdot 9) \\
2 \cdot 6(0 \cdot 6) \\
6 \cdot 4(0 \cdot 3)\end{array}$ \\
\hline $\begin{array}{l}\text { Chronic rheumatic disorders } \\
\text { Number of subjects } \\
\text { Mean (SEM) antibody level }(\mathrm{mm})^{*}\end{array}$ & $\begin{array}{l}\lg \\
\text { IgA } \\
\text { IgM }\end{array}$ & $\begin{array}{l}4 \\
4 \cdot 0(2 \cdot 4) \\
3 \cdot 0(1 \cdot 0) \\
6 \cdot 0(0 \cdot 2)\end{array}$ & $\begin{array}{l}3 \\
2 \cdot 2(2 \cdot 2) \\
3 \cdot 0(1 \cdot 5) \\
5 \cdot 8(0 \cdot 2)\end{array}$ \\
\hline $\begin{array}{l}\text { Group } C \\
\text { No rheumatic complaints } \\
\text { Number of subjects } \\
\text { Mean (SEM) antibody level }(\mathrm{mm})^{*}\end{array}$ & $\begin{array}{l}\text { IgG } \\
\text { IgA } \\
\text { IgM }\end{array}$ & $\begin{array}{l}16 \\
<3 \\
<3 \\
4 \cdot 0(0 \cdot 3)\end{array}$ & $\begin{array}{l}4 \\
<3 \\
<3 \\
4 \cdot 1\end{array}$ \\
\hline
\end{tabular}

${ }^{*}$ Antibody levels: a serum sample was considered as positive when the zone diameter in the diffusion in gel ELISA exceeded $6 \mathrm{~mm}$ for the IgG and IgA class, or $5 \mathrm{~mm}$ for the IgM class.

tConfidence limits with respect to rheumatic $v$ non-rheumatic subjects in group $\mathrm{A}$ for differences in sample $S 1$ in $\operatorname{IgM},-4 \cdot 8,-0.1(p<0 \cdot 05)$.

Table 4 Laboratory features of selected subjecs with chronic or relapsing rheumatic disorders

\begin{tabular}{|c|c|c|c|c|c|}
\hline \multirow[t]{2}{*}{ Laboratory feature } & \multicolumn{5}{|l|}{ Patient* } \\
\hline & $\overline{A l}$ & $B I$ & $B 2$ & $B 3$ & $B 4$ \\
\hline $\begin{array}{l}\text { Stool cultures } \\
\text { Acute } \\
\text { After } 5 \text { years } \\
\text { After } 7 \text { years }\end{array}$ & $\begin{array}{l}\mathrm{CJ} \\
\mathrm{Neg} \\
\mathrm{Neg}\end{array}$ & $\begin{array}{l}\mathrm{Neg} \\
\mathrm{Neg} \\
\mathrm{ND}\end{array}$ & $\begin{array}{l}\text { Neg } \\
\text { Neg } \\
\text { ND }\end{array}$ & $\begin{array}{l}\mathrm{Neg} \\
\text { Cl diff } \\
\text { ND }\end{array}$ & $\begin{array}{l}\mathrm{Neg} \\
\mathrm{Neg} \\
\text { ND }\end{array}$ \\
\hline $\begin{array}{l}\text { Antibody to } C \text { jejun } \\
\text { (IgG-IgA-IgM) } \\
\text { After 9-11 days } \\
\text { After } 30 \text { days } \\
\text { After } 5 \text { years } \\
\text { After } 7 \text { years }\end{array}$ & $\begin{array}{c}0-4-10 \\
10-8-12 \\
0-0-5 \\
0-0-0\end{array}$ & $\begin{array}{l}9-4-7 \\
0-5-6 \\
0-0-0 \\
\text { ND }\end{array}$ & $\begin{array}{l}7-0-6 \\
7-0-6 \\
0-0-0 \\
\text { ND }\end{array}$ & $\begin{array}{l}0-4-6 \\
0-4-6 \\
0-0-0 \\
\text { ND }\end{array}$ & $\begin{array}{l}0-6 \\
\text { ND } \\
0-0-6 \\
\text { ND }\end{array}$ \\
\hline HLA-B27 & Pos & Neg & Neg & Neg & Neg \\
\hline Diagnosis & $\begin{array}{l}\text { Incomplete } \\
\text { reactive } \\
\text { arthritis }\end{array}$ & $\begin{array}{l}\text { Arthralgia } \\
\text { enthesopathy }\end{array}$ & Sacroiliitis & Enthesopathy & $\begin{array}{l}\text { Probable } \\
\text { SLE }\end{array}$ \\
\hline
\end{tabular}

*Abbreviations: $\mathrm{CJ}=$ Campylobacter jejuni; neg=negative; pos=positive; $\mathrm{ND}=$ not determined; Cl diff $=$ Clostridium difficile. woman, previously healthy except for a herniated lumbar disc. Her mother is HLA-B27 positive and has been treated for chronic reactive arthritis.

Patient Al suffered from acute gastroenteritis with fever, diarrhoea, headache, abdominal pain, and attacks of vomiting, starting on the third day after the party. She was admitted to hospital on the sixth day after the party for five days, during which she experienced generalised muscle pain followed by arthralgia and lumbalgia. She described her locomotor symptoms as 'a severe flu with pain in my whole body'. The symptoms lasted for two to three months with a subsequent two months of absence from work. She perceived muscular weakness and tenderness, and complained of arthralgia and low back pain.

Patient Al had a positive stool culture for $C$ jejuni, positive $C$ jejuni serology and an erythrocyte sedimentation rate of $31 \mathrm{~mm} / \mathrm{h}$. A serological test for Salmonella DO complement fixation showed a titre of $1 / 80$, but stool cultures for salmonella were negative.

At follow up five and a half years after the infection she had no musculoskeletal symptoms and the routine laboratory tests were normal. Seven years after the party, however, she again experienced an episode of gastroenteritis followed by synovitis in the knees, elbow, wrist, and forefoot ten days later. This latter episode is regarded as a classical reactive arthritis. With some minor arthralgias, she was back at work after six months leave of absence. Testing for different gastrointestinal pathogens, including $C$ jejuni, was negative. The diagnosis was incomplete reactive arthritis.

\section{PATIENT B 1}

Patient B1 was a 22 year old HLA-B27 negative woman with no symptoms of acute enterocolitis. Three months after the party she developed pain in different finger joints, wrists, elbows, shoulder, and neck. She had difficulties in taking off her rings. At examination signs of enthesopathy were found on the right major trochanter and at several periarticular sites of the shoulder joints. Laboratory tests including erythrocyte sedimentation rate, antinuclear antibody, rheumatoid factor, and serum electrophoresis were normal.

Patient Bl was absent from work for four weeks and experienced symptoms for nine months. Every year since the infection, she has experienced similar episodes of arthralgias and enthesopathy lasting for weeks to months and followed by long symptom free intervals.

At the five and a half year follow up she suffered from generalised arthralgia, enthesopathy of the right shoulder, and a reduced grip strength. The erythrocyte sedimentation rate was $22 \mathrm{~mm} / \mathrm{h}, C$ reactive protein $31 \mu \mathrm{g} / \mathrm{ml}$ $(n<10)$ and she had an increased concentration of IgA rheumatoid factor. The diagnosis was arthralgia with enthesopathy.

\section{PATIENT B 2}

Patient B2 was a 29 year old HLA-B27 negative man with a hereditary hypercholesterolaemia. 
He had no symptoms of acute enterocolitis, but six to eight months after the party he developed chronic low back pain radiating downwards bilaterally. Pain was relieved by movements and by treatment with non-steroidal antiinflammatory drugs.

Medical examination five and a half years later showed decreased mobility of the lower back and signs of sacroiliitis. Radiography of the lumbar spine was normal, but suspected sacroiliacal erosions and iliacal sclerosis were found bilaterally. This finding was confirmed by a computed tomography scan of his sacroiliac joints. The diagnosis was sacroiliitis.

\section{PATIENT B 3}

Patient B3 was a 24 year old HLA-B27 negative woman with no symptoms of acute enterocolitis. Six months after the party she visited her general practitioner on several occasions owing to ankle pain. She has suffered from similar symptoms ever since. During pregnancy five years after the party she developed tendinitis of the thumb extensors. At the five and a half year follow up examination, enthesopathy of the ankle and thumb extensor tendinitis was found. The diagnosis was enthesopathy.

\section{PATIENT B 4}

Patient B4 was a 25 year old HLA-B27 negative woman with no symptoms of acute enterocolitis. Three months after the party she developed polyarthritis with an erythrocyte sedimentation rate of $68 \mathrm{~mm} / \mathrm{h}$ and antinuclear antibody titre $1 / 320$ homogeneous pattern. She was unable to work for six months to one year followed by recurrent periods of transient synovitis. During pregnancy her symptoms were aggravated.

At the five and a half year follow up the erythrocyte sedimentation rate was $4 \mathrm{~mm} / \mathrm{h}$, antinuclear antibody titre 1/80 and her major symptoms were fatigue and stiffness. The diagnosis was probable systemic lupus erythematosus.

\section{Discussion}

Previous reports have indicated that infection with $C$ jejuni may lead to rheumatic complications. ${ }^{4-10}$ This study of an outbreak of gastrointestinal disease following infection with $C$ jejuni reports the follow up of subjects regardless of the occurrence of gastrointestinal and/or locomotor symptoms at the acute stage. This has allowed a study of the effect of exposure to $C$ jejuni on the development of musculoskeletal complications in an entire exposed population. The frequency of arthritis following infection with $C$ jejuni varies between $2 \cdot 3$ and $24 \% .^{6-8}$ The genetic background of patients and the diagnostic criteria for arthritis may be an important factor in explaining this considerable variation. In one report dealing with a single outbreak of $C$ jejuni enterocolitis, ${ }^{10}$ the frequency of reactive arthritis was $1 \cdot 1 \%$ among 88 individuals with gastrointestinal symptoms. Our study shows that reactive arthritis occurred in one of 35 patients with gastrointestinal symptoms $(2 \cdot 9 \%)$.
In addition, four subjects ( $3 \cdot 8 \%$ ), three of whom were exposed to $C$ jejuni but without gastrointestinal symptoms, developed chronic or relapsing symptoms compatible with reactive arthritis. Thus, the incidence of rheumatic complaints associated with $C$ jejuni is higher than that previously reported for salmonella or shigella. ${ }^{20}$ This high incidence is even more puzzling considering the low occurrence of HLA-B27 positivity $(25 \%)$ in our patients compared with other studies of reactive arthritis. ${ }^{22}$ It is possible that $C$ jejuni or its degradation products display a high arthritogenic potential. Alternatively, host factors other than MHC class I molecules may predispose to arthritis following infection with $C$ jejuni.

The time between exposure to the microbial antigen and the onset of long term rheumatic disorders varied between 10 days (patient $A 1$ ), three months (patients B1, B4), six months (patient B3) and six to eight months (patient B2). A long delay between infection with $C$ jejuni and the start of locomotor symptoms suggests the role of a persisting bacterial antigen in the development of rheumatic complications.

The absence of overt signs of enterocolitis in the patients with delayed onset arthritis fits well with other reports suggesting that the symptoms and signs of infection are weak and short lived in patients with reactive arthritis. ${ }^{17} 18$ This is also in agreement with a study by Trull $e a^{19}$ in which four of eight patients with reactive arthritis following salmonella infection developed increased titres of antibodies to salmonella in the absence of gastroenteritis. The rheumatic symptoms appearing during or shortly after the infection with $C$ jejuni do not show the classical picture of reactive arthritis, with the exception of patient A1. The finding of myalgias, arthralgias, and backache during campylobacter enteritis has also been reported by Blaser et al. ${ }^{21}$

The levels of antibodies to $C$ jejuni corresponded well to the intensity of the diarrhoeal disease. There was a marked difference with respect to IgG and IgA responses to antibodies to $C$ jejuni between subjects with overt gastrointestinal illness (group A) and those without gastrointestinal symptoms (groups B and C). We interpret the increased IgM levels in group $B$ as a sign of a recent subclinical infection. The fact that the antibody titres in the first and second sample did not change significantly in group B was probably due to the delay in testing, i.e. the IgM antibody response had already taken place when the first sample was collected. The patients with acute rheumatic complaints had a more pronounced IgM antibody reaction against $C$ jejuni than the nonrheumatic patients in group $A$, although the levels of $\operatorname{IgA}$ and $\operatorname{IgG}$ antibodies to $C$ jejuni were not significantly different.

The questions of whether some subjects had another infection between the party and the onset of chronic rheumatic disorder is important. Two patients (B1, B3) had a common cold some weeks before the onset of the rheumatic disorders. No other infections were reported.

Patient Al had two episodes of reactive arthritis. The first an incomplete reactive arthritis, was clearly associated with $C$ jejuni. The 
second episode of classical reactive arthritis seven years later was preceded by a gastrointestinal disease of unknown origin. Stool cultures and serological examination did not favour a reinfection with $C$ jejuni. In this patient the heredity (HLA-B27 positivity and a mother with chronic reactive arthritis) seemed to predispose the patient to arthritic reactions in response to different bacterial agents.

Patient Bl showed increased levels of $\operatorname{IgA}$ rheumatoid factor and an intermittent pattern of disease. Palindromic rheumatism could be a differential diagnosis, but the predominance of enthesopathy favours a reactive disorder. Also, an increased concentration of IgA rheumatoid factor is a common finding in patients with reactive arthritis. ${ }^{14}$ Patient B4 had a systemic rheumatic disease, probably systemic lupus erthythematosus. There is no evidence that $C$ jejuni is an aetiological agent in systemic lupus erythematosus or similar diseases. Nevertheless, campylobacter infections may change the natural course of a systemic rheumatic disease into a more aggressive form through polyclonal B cell activation. ${ }^{15} 16$

In conclusion, we found that acute rheumatic complaints are common following $C$ jejuni entercolitis. $C$ jejuni is associated with chronic rheumatic disorders, even in patients without the initial symptoms of gastrointestinal infection.

We thank Dr Andrzej Tarkowski for valuable discussions. This study was supported by grants from the Göteborg Medical Society.

1 Reiter H. Über eine bisher unbekannte Spirocheteninfektion (Spirochaetosis arthritica). Dtsch Med Wochenschr 1916; 42: 1435-6.

2 Fiessinger N, LeRoy E. Contribution à l'étude d'une épidémie de dysenterie dans le Somme (Juillet-Octobre 1916). Bull Soc Med Hop Paris 1916; 40: 2030-69.

3 Urman J D, Zurier R B, Rothfield N F. Reiter's syndrome associated with Campylobacter fetus infection. Ann Intern Med 1977; 86: 444-5.

4 Berden J H M, Muytjens H L, van de Putte L B A. Reactive arthritis associated with Campylobacter jejuni enteritis $B M \mathcal{F} 1979$; i: 380-1.

5 Weir W, Keat A C, Welsby R D, Brear G. Reactive arthritis associated with Campylobacter infection of the bowel. fInfect 1979; 1: 281-4.

6 Kosunen T U, Pönkä A, Kauranen O, Martio J, Pitkänen T, Hortling L, Aittoniemi S, Penttilä O, Koskimies S. Arthritis associated with Campylobacter jejuni enteritis. Scand f Rheumatol 1981; 10: 77-80

7 Gumpel J M, Martin C, Sanderson P J. Reactive arthritis associated with Campylobacter enteritis. Ann Rheum Dis 1981; 40: 64-5.

8 Johnsen K, Östensen M, Schmidt Melbye A C, Melby K. HLA-B27 negative arthritis related to Campylobacter jejun enteritis in three children and two adults. Acta Medica Scandinavica 1983; 214: 165-8.

9 Van de Putte L B A, Berden J H M, Boerbooms A M T, Muller W H, Rasker J J, Reynvaan-Groendijk A, van de Linden S M J P. Reactive arthritis after Campylobacte jejuni enteritis. F Rheumatol 1980; 7: 531-5.

10 Eastmond C J, Rennie J A N, Reid T M S. An outbreak of Campylobacter enteritis - a rheumatological follow up survey F Rheumatol 1983; 10: 107-10.

11 Skirrow M B. Campylobacter enteritis: a 'new' disease. $B M \mathcal{Y}$ 1977; ii: 9-11.

12 Svedhem $\AA$, Gunnarsson H, Kaijser B. Diagnostic serology of Campylobacter jejuni infections using the diffusion-in-gel Campylobacter jejuni infections using the diffusion-in-gel enzyme-linked immunosorbent assay, DIG-E

13 Bradley J W. Distribution free statistical tests. New York Prentice Hall, 1968

14 Gripenberg $M$. Common serological features in rheumatoid arthritis and yersinia arthritis. Scand $\mathcal{F}$ Rheumatol 1981; 10: 85-91.

15 Möller E, Ström H, Al-Balaghi S. Role of polyclonal activation in specific immune responses. Scand 7 Immunnol 1980, 12: $177-82$.

16 Banck G, Forsgren A. Many bacterial species are mitogenic for human blood B lymphocytes. Scand I Immunol 1978; 8 for hum

17 Wright V. Reiters' disease. In: Scott J T, ed. Copeman's textbook of rheumatic diseases. 6th ed. Edinburgh: Churchill Livingstone, 1986: 787-805.

18 Toivanen A, Granfors $K$, Lahesmaa-Rantala $R$, Leino $R$ Ståhlberg T, Vuento R. Pathogenesis of yersinia-triggere reactive arthritis: immunological, microbiological and clinical aspects. Immunol Rev 1985; 86: 47-70.

19 Trull A K, Eastmond C J, Panayi G S, Reid T M S. Salmonella reactive arthritis: serum and secretory antibodies in eight patients identified after a large outbreak. Br f Rheumatol 1986; 25: 13-9.

20 Keat A C. Reiter's syndrome and reactive arthritis in perspective. N Engl f Med 1983; 309: 1606-15.

21 Blaser M J, Berkowitz I D, LaForce F M, Cravens J, Reller L B, Wang W-L L. Campylobacter enteritis: clinical and epidemiologic features. Ann Intern Med 1979; 91: 179-85.

22 Van de Putte L B A, van Riel P L C M. Reactive arthritis associated with Campylobacter enteritis. In: Mielants $H$, Veys E M, eds. Spondylarthropathies: involvement of the gut. Amsterdam: Elsevier, 1987: 97-102. 